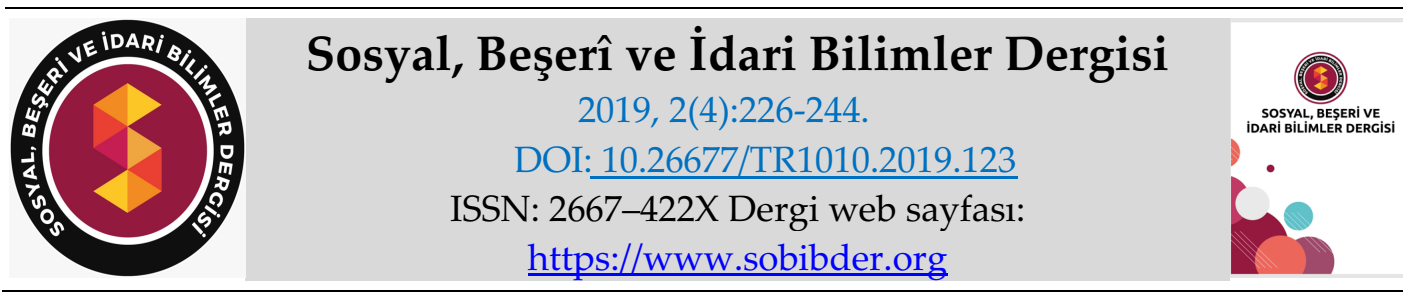

ARAȘTIRMA MAKALESI

\title{
Dört Özgün Trabzon Hamamı
}

Filiz UÇAR, Hacı Bayram Veli Üniversitesi, Sanat Tarihi Bölümü Yüksek Lisans Öğrencisi, eposta: romeoguz4448@gmail.com

ORCID: https://orcid.org/0000-0001-8134-8823

Öz

1461 yılında, Fatih Sultan Mehmet tarafından fethinin ardından hızlı bir şekilde imar faaliyetlerine girişilen Trabzon kent merkezinde, pek çok yapı ile beraber önemli sayıda hamam da inşa edilmiştir. Trabzon İl Merkezindeki hamamlara ilişkin arşiv kayıtlarında ve yayınlarda yirmi tarihi hamam yapısından söz edilir. Bunlardan bazıları, fetih öncesine ait olmakla birlikte şehrin Türkleşmesinin ardından onarılarak kullanılmaya devam edilen İçkale Saray Hamamı, Çifte Hamam ve daha çok Hacı Kasım Hamamı olarak tanınan Fatih Hamamı ile günümüze ulaşmayan Kule Hamamı olarak bilinen yapılardır. Fetihten sonraki dönemde şehirde 12 hamamın inşa edildiği bilinmektedir. Bunlardan günümüze ulaşanlar; İmaret, Tophane, İskender Paşa, Sekiz Direkli, Alaca, Hacı Arif, Meydan ve Askeriye Hamamlarıdır. Tekfur Sarayı (İçkale Saray hamamı olabilir), Tekfur Çayırı, Kahyaoğlu, Çukur, Çömlekçi, Kral Kızı ve Gâvur hamamları günümüze ulaşmamıştır. Bu incelemede, Trabzon il merkezinde bulunan hamam yapılarından günümüzde halen varlığını ve işlevini sürdüren, mimarlık ve sanat tarihi yanı sıra, kent kültürü ve sosyal tarih açısından da önemli, dört özgün hamam yapısı değerlendirilmeye çalışılmıştır.

Anahtar Kelimeler: Kültür Varlı̆̆ı, Türk Mimarlığı, Tarihi Trabzon Hamamları.

Makale Gönderme Tarihi: 04.03.2019

Makale Kabul Tarihi: 14.05.2019

\section{Önerilen Atıf:}

Uçar, F. (2019). Dört Özgün Trabzon Hamamı, Sosyal, Beşeri ve İdari Bilimler Dergisi, 2(4):226-244.

(C) 2019 Sosyal, Beşerî ve İdari Bilimler Dergisi. 


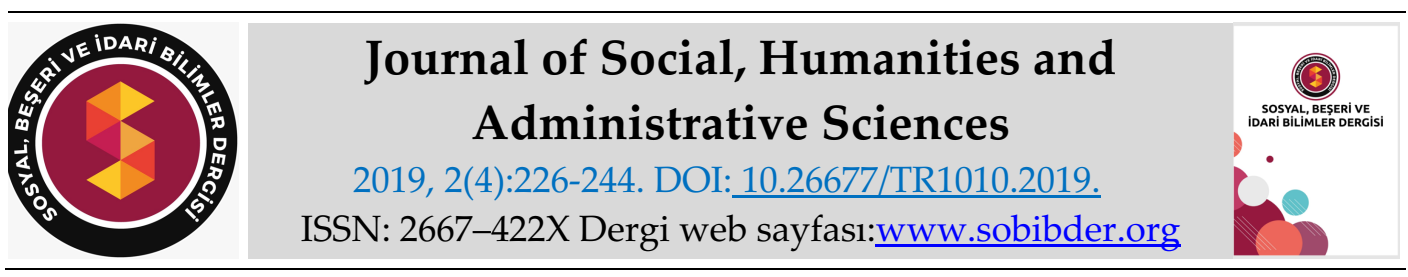

\title{
$\underline{\text { RESEARCH PAPER }}$
}

\section{Four Original Trabzon Bath}

Filiz UÇAR, Hacı Bayram Veli University, Art History Department, Graduate Student, e-mail: romeoguz4448@gmail.com

ORCID: https://orcid.org/0000-0001-8134-8823

\begin{abstract}
In the year 1461, after the conquest by Fatih Sultan Mehmet, the city was built in the city center. In the archive records and publications related to the baths in Trabzon City Center, twenty historical baths are mentioned. Some of them belong to the pre-conquest of the city, the Turkization of the city, the restoration of which continues to be used in the İçkale Palace Bath, the Double and more known as the Hacı Kasım as the Fatih Bath, known as the Tower Baths are not known structures. It is known that 12 baths were built in the city after the conquest. Those who have survived to this day; Imaret, Tophane, Iskender Pasha, Eight Direkli, Alaca, Haci Arif, Meydan and Askeriye. Tekfur Palace (İçkale Saray can be), Tekfur Meadow, Kahyaoğlu, Çukur, Çömlekçi, Kral Kızı and Gâvur baths have not survived. In this study, four original bath structures which are important in terms of urban culture and social history were tried to be evaluated.
\end{abstract}

Keywords: Cultural Presence, Turkish Architecture, Historical Trabzon Baths.

Received: 04.03.2019

Accepted: 14.05 .2019

Suggested Citation:

Uçar, F. (2019). Four Original Trabzon Bath, Journal of Social, Humanities and Administrative Sciences, 2(4):226-244.

(c) 2019 Sosyal, Beşerî ve İdari Bilimler Dergisi. 


\section{Gíriş}

Trabzon, çağlar boyunca, pek çok bakımdan, kadim Anadolu coğrafyasının Doğu Karadeniz bölgesindeki en önemli şehirlerinden birisi olmuştur. Tarihte ilk yerleşimin İ.Ö. ikinci bin civarında gerçekleştiği düşünülen yörede, Trabzon kent temelleri de İ.Ö. 7. Yüzyılda Miletos'lu kolonistlerce atılmıştır. Takip eden dönemlerde çok sayıda kültüre yurtluk eden Trabzon ve çevresi daha sonra Perslerin, Pontus devletinin, Romalıların ve Bizanslı Komnenosların hâkimiyetine girmiştir. Şehir merkezi ve yakın çevresi 1461 yılında Fatih Sultan Mehmet tarafından fethedilerek Osmanlı topraklarına katılmıştır (Öksüz, 2005:11).

Fetihten sonra Trabzon kenti ve çevresindeki sosyal durumu tespit ettiği bilinen eski Osmanlı arşiv kaydı Maliyeden Müdevver 828 numaralı 1486 tarihli defterdir ${ }^{1}$. Bu defterin ilk sayfalarında verilen bilgilere göre fetihten sonra, Trabzon kent merkezini teşkil eden kale içi, Hıristiyan unsurlardan arındırılıp Tokat, Çorum, Amasya ve Samsun havalisinden getirilen halkın iskânına açlarak şehrin ilk Türk-Müslüman mahalleleri oluşturulmuştur (COAB, 828 no'lu 1486 Tahrir Defteri).

Trabzon'u ziyaret eden Evliya Çelebi kenti; "Karadeniz'in doğusunda körfez gibi bir denizin üzerinde kurulmuş, İrem bağına benzer, süslü bir yer" olarak tasvir eder (İnan, 1998:162-165).

\section{HAMAMLAR VE TÜRKLERDE HAMAM YAPILARI}

Yıkanma ve temizlikle vücut bakımı fikri yeni bir düşünce değildir. Çok eski zamanlardan beri dini amaçlarla da olsa buna büyük önem verilmiş, bu bakımı sağlayan bina ve tesislerin inşası, çeşitli coğrafyalarda çok eski çağlarda başlamıştır (Aru, 1949:9).

Arapçada "isıtmak; sıcak olmak" anlamındaki hamm (hamem) kökünden türeyen hamam (hammam) kelimesinin sözlük anlamı "ısıtan yer" demek olup "yıkanma yeri" anlamında kullanılmıştır. Hamam, suyun ısıtılması suretiyle insanların yıkanması için yapılmış bir tesistir (Eyice, 1997:402).

Değişik coğrafyalarda farklı kültürler, suda, günahları ve bütün fenalıkları giderici gizli bir kuvvetin varlığına inanmışlardır. Nitekim Hintliler Ganj nehrini, Asurlular Fırat'1, Mısırlılar Nil'i mukaddes saymışlar, yılın belirli günlerinde bu nehirlerin sularında yıkandıktan sonra kendilerini bütün günahlarından kurtulmuş kabul etmişlerdir. Bu tür inançların günümüze ulaşmış yapı kalıntıları bulunmakla beraber, bu su kültünden söz eden eski kaynak yayınlarda vardır (Aru, 1949:9).

Bugünkü Pakistan'ın batısında Sind'de yapılan tarih öncesi çağlara ait kazılarda, İ.Ö. 2500-1500 yıllarındaki İndus Medeniyetinin en önemli şehri olan Mohenjo Daro meydana çıkarıldığında tespit edilen çok gelişmiş bir su ve kanalizasyon sistemi burada var olan hamam yapılarının izlerine ulaştırmıştır. Eski Mezopotamya'da yapılan kazılarda da dünyanın en eski hamamı olarak kabul edilen Asur hükümdarlarına ait bir yıkanma tesisinin yapı kalıntılarına ulaşılmıştır. Dicle kıyısındaki Asur'da da Kral III. Salmanasar'ın yaptırdığı yapılar içinde (M.Ö. 859-824) bir hamamının varlığ tespit edilmiştir (Eyice, 1993:403). Mısır'da Tel-el Amarna'da eski hamamlara rastlandığı gibi, bugünkü Türkiye-Suriye sınırı kenarında Viran şehre yakın Re'sül'ayn dolaylarında Tel Halaf'ta, milattan önce III. Yüzyıla ait bir kent kalıntısında evlerde banyo yapmak için özel mekânların bulunduğu anlaşılmıştır. Anadolu'da, Gaziantep'in İslâhiye ilçesi dolaylarındaki Zincirli höyük'te yapılan kazılarda da milattan önce 1200 yıllarına doğru büyük 
Hitit Devleti yıkıldıktan sonra kurulan Geç Hitit devletlerinden biri döneminde yapılmış bir hamam kalıntısı bulunmuştur (Eyice, 1993:403).

Eski Yunan çağında Mimarlık ürünleri arasında sık görülmeyen hamam yapıları Roma Çağında, halkın ortak olarak kullandığı gimnazyum, kütüphane gibi diğer yapılarla birleştirerek çok büyük mimari kompozisyonlar meydana getirilmiştir. Roma, hamamlarının fonksiyon bakımından belirli özel hacimleri vardır (Kuban, 1977:52).

Halka açık hamam mimarisi Roma çağında ortaya çıkmış ve geliştirilmiştir. Milattan önce I. yüzyıla doğru yaşadığı sanılan Sergius Orata adlı bir mimarın ilk defa sıcak hava ile merkezi ısıtma sistemini meydana getirdiği ve bunun Roma hamamlarında uygulanması ile bu türden yapıların yaygınlık kazandığı kabul edilir.

Hamam yapılarının, en azından plan ve örtü sisteminin şekillendirdiği konstrüksiyon formunun Emevi döneminde Hiristiyan sanatı aracılığı ile Roma geleneğinden alındığı söylenebilir (Ünver, 1950:198 ve Aru, 1949:30). Erken İslam sanatının Emevi dönemi örnekleri içinde seçkin bir yer teşkil eden Emevi çöl saraylarındaki gelişkin mimari form ve süslemeleriyle öne çıkan hamam yapıları arkaik düzeyin ötesinde özelliklere sahip yapılardı (Başkan, 2014:51-52). Roma hamamlarının İslam hamamları ile en büyük benzerliği ısıtma sisteminde görülür. "Caldarium"un döşemesi, üst üste istiflenerek oluşturulmuş tuğla payelerin üzerine otururdu. Yakılan odunların verdiği sıcaklık, "hypocaustum"(Aru, 1949:14 ve Eyice, 1997:403) denilen bu bodrumda tuğla payelerin arasında dolaşır ve gerek "tepidarium" u gerek "caldarium" $u$ tabandan ısıtırdı. Odunların dumanı ile buhar duvarların içine yerleştirilen pişmiş toprak künklerin yardımı ile dışarı atılırdı.

Türk Hamamı'nın plan ve mekân gelişimine bakıldığında da Roma ve özellikle Bizans mimari geleneklerinin izleri belirgindir. Bu yapıların Osmanlı döneminde toplumsal hayatın bir parçası haline gelmesi de bu eski geleneklerle ilişkilidir. Ancak hamam yapılarını tümüyle Türk mimarlık geleneğinin Anadolu sürecinde tanıdığını veya Türk insanının toplumsal yaşamına Anadolululaşma ile birlikte girdiğini düşünmek de gerçekçi bir yaklaşım olmaz (Başkan, 1999:4247). Çünkü 12. yüzyıldan çok daha önce Büyük Selçuklular, o sırada henüz gelişmekte olan İran ve Hazar Denizi kıyısındaki İslami hamamlarla karşılaşmalarının da etkisiyle hamam tasarımı ve geleneğine taze bir enerji kazandırmışlardır (Yegül, 2009:105).

Anadolu'nun fethinden önce, Türklerin yaşadıkları bölgelerdeki hamam mimarisine ilişkin, Batı Türkistan' da geç Uygur kentleri ile Karahanlı yerleşimlerindeki basit form ve ölçülerdeki hamam üniteleri bir yana, günümüze ulaşmış mimari kurgusu Anadolu'yla bağlantılandırılabilecek anıtsal örnekler henüz ortaya çıkarılabilmiş değildir. Ancak Anadolu Selçuklu saraylarındaki gelişkin plan ve mekân anlayışına sahip hamam örnekleri en azından büyük olasılıkla gelişim süreci daha önce başlayan ve Büyük Selçuklu döneminde benzer erken örneklerinin var olabileceğine işaret eder. Özellikle, 1053-1068 yılları arasında Batı Karahanlı Devletinin başkenti olan Semerkant' daki kadim Efrâsiyâb höyügü üzerinde Timurlu döneminde kümelenerek oluşan Şah-ı Zinde Türbelerinin bulunduğu tepenin kuzey batı ucunda Batı Karahanlı Hakanı Nasr b. İbrahim Böri Tigin Tamgaç Buğra Kara Han'ın 11. Yüzyılın üçüncü çeyreği içinde yaptırdığı küçük külliye içinde kare planlı muhtemelen dört eyvanlı küçük bir hamam/yunak yapısının izleri; Selçuklu öncesi Karahanlı döneminde bu yapı türünün arkaik örneklerinin var olduğuna ilişkin bir örnek kabul edilebilir (Başkan, 2012:131). Nasıl bir hamam inşa ettiklerine dair bilgi yoktur. Bununla birlikte Göçebe Türklerde deriden yapılmış ve 'çerge' denilen çadır hamamları olup, burada yıkandıkları bilinmektedir. Türklerin hamama verdikleri bu önem, konakladıkları yerlerde çadır hamamları kurmalarından da anlaşılmaktadır. I. Alâeddin Keykubad, Anadolu' da 
'sefer hamamı' (Eyice, 1997:412) denilen bir çadır-hamam ile birlikte sefere çıkıyor; altın, gümüş takımlar, amber kokular bu hamamın levazımatında bulunuyor idi. Harzemşahlar ordusunda da mevcut olan bu tür bir hamam eski adıyla 'çerge' ismini muhafaza ediyordu. Yarı göçebe olan Akkoyunlular'ın da çergeyi (Turan, 1997:346) kullandıkları bilinmektedir.

Orta Asya'dan küçük Asya'ya gelen Selçuk Türkleri, vücut bakımı ve dinin emrettiği temizlik ve ananelere göre basit ihtiyaç binaları inşa etmişlerdir (Aru, 1949:29). Anadolu'daki köşsk, saray, han, kışla veya tekke hamamları gibi sınırlı sayıda insanın yıkanması için düşünülmüş ve hacimleri buna göre boyutlandırılmış küçük ölçüde tek hamam örnekleri, özel hamamlar adıyla ayrı bir grup teşkil ederler. Bunlar bazen müstakil veya yarı müstakil, bazen de yapı kütlesinin bütünü içinde yer alan muhtelif hacimler halinde planlanmışlardır. Bu gruptaki bazı örneklerde soğukluk veya helâların bulunmadığı, sıcaklıkların da bir veya iki hacimden ibaret olduğu görülür (Önge, 1988:404).

Alara kalesi tepesinde inşa edilmiş olan hamamlı kasır gerek planı gerekse figürlü freskleri ile XIII. Yüzyıl Anadolu mimarisinde önemli bir yer alır. Anadolu Selçuklularından günümüze kadar kalabilmiş tek eser olması önemini arttırır. Hamamlı kasır ve süslemeleri İslam mimarisinde çok eski bir gelenek olan ve ilk abidevi örnekleri Emevi mimarisinde görülen hamamlı kasır fikrinin çok mütevazı bir ölçüde de olsa Anadolu Selçuklularındaki devamını gösterir. XIII. Yüzyıl Anadolu Selçuklu köşk ve sarayları içinde bugüne kadar hamamlı bir kasır tespit edilememiştir. XIII. yüzyıl Anadolu mimarisinde hamamlı kasır tipini devam ettiren çok önemli bir eser, Diyarbakır iç kalesinin tepesinde inşa edilmiş olan Artuklu sarayıdır (Yetkin, 1972:119).

Anadolu'da bilinen en eski çifte hamamlar Kayseri Külük ve Sultan Hamamlarıdır. Selçuklu döneminin çifte hamamlarında plân düzeni, genellikle aradaki müşterek duvar boyunca ve her iki kısımda ard arda sıralanan soyunmalık, aralık, soğukluk, sıcak su deposu ve sicaklık mahalleriyle bunların nihayetinde müştereken yer alan sıcaklık ve külhandan ibarettir. Bu şema sonraları XV ve XVI. yüzyıllarda da tekrarlanmış olmakla beraber, bazı farklı tertiplerin de denendiği görülmektedir.

Selçukluların hamama ne derece önem verdikleri yaptırdıkları Saray hamamlarından da anlaşılmaktadır. Alâeddin Keykubad'ın Kubadabad ve Kayseri Keykubadiye'deki saray hamamlarının izleri göstermektedir ki hamam sarayların vazgeçilmez yapılarından biridir. Özellikle zengin çini süslemeleriyle bezenen yapılar bugüne ulaşamasa da adından söz ettirmektedir (Arık, 2000:19-21).

"Dünyanın en temiz insanları Tanrıdă̆ yöresinde yaşamış olan Oğuzlardı" diyen, E.B. Şapolyo; "Türkler obalarını pınar başlarına veya su kenarlarına kurarlar, kadını erkeği bol bol yıkanırlardı. Hıristiyanlar vaftiz olduklarından az yıkanırlar pis kokarlardı. Arap aşiretleri su bulamadıklarından pistiler. Müslümanlık bu insanların temiz olmalarını săglayabilmek için birçok yeni kurallar getirmiştir. Ancak Türklerin temizlik anlayışı Müslümanlık kurallarından önce kendi törelerinden gelmektedir" (Şapolyo, 1967:10-11) diye bahseder.

Hamam kelimesinin Türkçedeki en eski karşıllğı 'munça' veya 'munçak'tır. Bu kelimeyi Kuzey Türkleri ile Çuvaşlar da kullanmıştır. Daha sonra görülen 'çimek', 'yunak', 'yıkak', 'yunluk' uzun bir geçmişe sahip olup çeşitli Türk boyları arasında bugün de kullanılmaktadır. Hamam karşılığ olarak 1sı, 1sıcak, 1sıdam, 1sık, isik, issi gibi kelimeler yalnız Anadolu'da değil diğer Türk kültür çevrelerinde de yaygınlık kazanmıştır. Bugün Türkiye' nin bazı yörelerinde hamama sıcak (ısıcak) denilmektedir. Mısır ve Kıpçak Türklerinde ise hamama ılı su (yılı su) adı verilmiştir. "Kudret hamami, kaplıca anlamındaki ılıca (ilı̆gca) kelimesi de buradan gelmektedir" (Uzun ve Albayrak, 1997:430-433). 
Türklerde hamam, kentlerin, yerleşim yerlerinin vazgeçilmez bir unsuru olmuştur. Selçukluların Anadolu topraklarına yerleşmesiyle her tarafta hamamlar yapılmaya başlanmıştır. Hamama en fazla önem veren Osmanlı Türkleri olmuş ve devletin sınırlarının ulaştığı her yerde irili ufaklı hamamlar yapılmıştır. Bunların dışında büyük konaklarda, varlıklı kişilerin evlerinin yanında küçük ölçüde özel hamamlarda yapılmıştır. Küçük yerleşim yerleriyle evlerde ise 'gusülhane' denilen yıkanma yerleri inşa edilmiştir (Eyice, 1997:431).

Genellikle büyük kentlerde külliyeler içerisinde, daha çok çifte hamam olarak planlanan hamamlarda erkekler kısmı giriş ve çıkışı ana caddeye bakarken, kadınlar kısmında giriş ve çıkış mahremiyet olgusuna bağlı olarak arka caddeye, işlek olmayan tali yola bakacak şekilde inşa edilmiştir.

Küçük yerleşim yerleri, ilçe ve kasabalarda daha küçük boyutta ve genellikle tek fonksiyonlu hamamlar inşa edilmiştir. Tarihi Türk kentlerinin önemli sosyal yapıları da olan hamamlar çoğunlukla kadınlar ve erkekler için ayrı ayrı faaliyet göstermiştir. Fakat tek hamamlarda ihtiyaca göre haftanın belli gün ve saatlerinde kadınlara da hizmet verilmiştir. Hamamların çoğunlukla Çifte hamam olarak yapılması ısıtma sistemi açısından büyük kolaylık sağlayarak 1 sı dağılımını dengelemiş, dolaşım tek bir hattan iki yöne de aktarılmıştır.

Anadolu'daki Türk hamamları yukarıda da ifade edildiği gibi Antik kültürlerden etkilenmekle birlikte tasarımın temeli Türklerin kendi mimarlık gelenekleri üzerine oturmuştur. İşlev açısından yıkanma ihtiyacı esas alınmış olup dinsel inançların örf ve adetlerin gereklilikleri mimariye uyarlanmıştır. Giderek geliştirilen bu yapıların plan şemaları, kitle anlayışı ve iç estetiği ile orijinal bir yapı tipine dönüşmüş ve "Türk Hamamı"şeklinde evrensel bir kimlik kazanmıştır (Erat, 1997:29).

Anadolu Türk Hamamları başlıca; soyunmalık, aralık, ılıklık, sıcaklık bölümleri ile su deposu, külhan (Önge, 1995:9) ve cehennemlikten oluşan tesisat kısımlarından meydana gelmiştir. S. Eyice'ye göre Türk Hamamları, sıcaklıklarının plan şemaları göz önünde tutularak;

a) Haçvari dört eyvanlı ve köşe hücreli tipi

b) Yıldızvari sıcaklıklı tip

c) Kare bir sıcaklık etrafında sıralanan halvet hücreli tip

d) Çok kubbeli sıcaklıklı tip

e) Ortası kubbeli, enine sıcaklıklı ve çifte halvetli tipi

f) Soğukluk-sıcaklık ve halvet eş odalar hâlinde, altı gruba ayrılır (Eyice, 1960:99-120).

\section{ARŞIV KAYITLARINDA TRABZON HAMAMLARI}

Arşiv kayıtlarından anlaşıldığına göre Trabzon'la ilgili en eski kaynak Trabzon Sancağına ait Maliyeden Müdevver 828 numaradaki 1486 tarihli tahrir defteridir. Trabzon'un sosyal durumunun aktarıldığı bu defterde Trabzon'daki Çifte Hamam'ın adı Mahalle-i Mescidi Amasya der Mezd-i Hamam-1 Çifte diye geçmektedir (Lowry, 1981:24-25). Trabzon Sancağına ait 1583 tarihli tapu tahrir defterinde İmâret-i Hatuniye Vakfı'nın gelirleri arasında imaret yakınındaki bir hamamdan ve yine Orta Hisar'da bir hamamın varlığından (Bostan, 2002:400) söz edilir.

Yine Evliya Çelebi, "Seyahatname"sinde, Trabzon'un Hamamlarından;"Orta hisar'da iki güzel hamam vardır ki, biri kale duvarının Aşağı Hisar'a açılan kapısı yanında hava su ve yapısı güzel kadınlara ve erkeklere hizmet eder çifte hamamdır. Diğeri iç kalenin kuzey tarafında duvara yakındır. Kule hanı derler ki suyu ve havası güzel kâfirlerden kalma bir hamamdır. İmaret hamamı Hatuniye Camii'nin yakınındadır. 
Aşă̆ı Hisar hamamı Güzel bir hamamdır. İskender Paşa hamamı çifte ve gayet ferah bir hamamdır. Kâfir Hamamı Yeni Cuma Mahallesi ile kâfir meydanı arasında havası hoş bir hamamdır. Tekfur Sarayı Hamamı güzel bir hamamdır Bunlardan başka iki yüz kırk beş kadar özel saray hamamları dahi vardır" (Çelebi, 1993:457) diye bahsetmektedir.

Mehmet Âşık'ın XVl. yy'da yazdığı Menazirü'l Avalim adlı genel coğrafya eserinde; Trabzon hamamlarından yedi tanesi isimleriyle zikredilerek (Usta, 1999:41-44) o dönemki durumlarına kısaca değinilmektedir. Trabzon şehrinin sosyal yapısına ışık tutan bir diğer kaynakta Kadı Sicilleri'dir. 1643-1656 (İnan, 1998:183-184) yıllarını kapsayan arşiv belgelerinde Trabzon şehrindeki hamamların vakıfların birer akarı olarak önemli bir yer aldığı görülmüştür. Sicillerdeki kayıtlara yansıdığı kadarıyla Trabzon'daki hamamların o dönemki ekonomik durumu hakkında bilgiler verilmektedir.

XVII. yüzyılın ikinci yarısında Trabzon şehrinin sosyal ve ekonomik hayatında Şer'iyye Sicillerinin son derece önemli bir yeri vardır. İmaret-i Hatuniye Vakfının hamamlarıyla ilgili Maliyeden Müdevver Defterlerde H. 26 Cemaziyelahir 1000 (M. 9 Nisan 1592) tarihli belgede (Usta, 2016:225-250) Trabzon'daki hamamların durumundan bahsedilmektedir. Yine aynı Şer'iyye Sicilinde de şehirdeki Tekfur Çayırı hamamının gelirlerinden (Türkmenoğlu, 2016:168) bahsedilmektedir.

V. Usta'nın Feruhan Bey'den (Usta, 1999:131) aktardığına göre; Trabzon'un 12 hamamından Kahyaoğlu, Paşa, Alaca, Çukur, Gâvur adlarını taşıyan batı varoşta; Moloz, Uzunoğlu, Meydan, Yokuzoğlu, denilenler İçkale' de; Çifte ve Kuleli, Orta hisar'da; İmaret hamamı da Zağanos kapısı dışında bulunur. Bunlardan Meydan, Paşa ve Çifte hamamlar erkek ve kadınlara mahsus olmak üzere iki bölümdür. Tek bölümlüler de öğleye kadar erkeklere, öğleden sonra kadınlara tahsis edilir (Usta, 1999:131). 1881 yılı Vilayet salnamesinde (Eser, 2003:118) Trabzon sancağında 123 hamamın olduğu belirtilmektedir.

J. H. Lambert'in 1937-38-39 Trabzon İmar planı ve İzah raporu (Tuluk ve Düzenli, 2010:319) Trabzon hamamları hakkında o dönemki duruma ışı tutmaktadır. Yine Sedat Çetintaş; Hazırladığ 13 sayfalık daktilo ile yazılmış “Trabzon'un Sanat Eserleri” raporunu 18 Ağustos 1937 tarihinde Kültür Bakanlığına sunmuştur (Tuluk ve Düzenli, 2010:353).

\section{Trabzon Hamamları}

Trabzon İl Merkezinde tarihsel süreç içerisinde çok sayıda hamam yapısı inşa edildiği anlaşılmaktadır. Arşiv kayıtlarında yer alan hamamlardan çoğu günümüze kadar gelememiştir. Günümüze ulaşanların ise büyük bölümü kaderine terk edilmiş olup ya birkaç duvar parçası kalmış ya da yıkık dökük durumdadır. Trabzon'da geçmişten bugüne gelen hâlihazırda yalnızca 4 yapı koruma altına alınarak, geçirdiği onarımlar sayesinde varlığını sürdürerek halen hamam olarak faaliyetine devam etmektedir.

Sekiz Direkli Hamam, Pazar kapı mahallesi, sekiz direkli hamam sokakta bulunan Kadastral planda 26 pafta 79 ada 3 parselde kayıtlıdır. Tarihi Sekiz Direkli hamam, Trabzon Kültür Varlıklarını Koruma kurulunca 14/12/1974 gün sayılı kararı ile anıtsal tescilli yapı olarak 8195 sayılı kanun çerçevesinde taşınmaz kültür varlığı olarak tescil edilerek koruma altına alınmıştır.

Fatih Hamamı (Hacı Kasım), Cumhuriyet mahallesi, 36 pafta, 208 ada, 5 parselde olup, Trabzon Kültür Varlıklarını Koruma kurulunca 04/09/1985 gün ve 1410 kararı ile korunması gerekli kültür varlığı olarak tescillenmiştir. 
İskender Paşa Hamamı, Çarşı Mahallesi, Paşa hamam sokakta 31 pafta, 180 ada, 12 parselde yer alan hamam 04/09/1985 gün ve 1426 kararı ile korunması gerekli kültür varlığı olarak tescillenmiş ve bu karar çerçevesince çeşitli onarımları yapılmıştır.

Meydan Hamamı, Kemerkaya Mahallesi, Meydan hamamı sokak Maraş caddesi üzerinde 268 ada, 7 parselde bulunan yapı, Trabzon Kültür Varlıklarını Koruma kurulunca 04/09/1985 gün ve 1426 sayılı kararı ile taşınmaz kültür varlığı olarak tescil edilmiştir.

\section{Sekiz Direkli Hamam}

Pazar kapı mahallesinde, sekiz direkli hamam sokakta yer alan bu hamamın kimin tarafından ve ne zaman yapıldığı kesin olarak belli olmamakla birlikte Bizans döneminde şehrin Müslüman sakinleri tarafından yapıldığı söylenir. Üst örtü biçimi göçebe Türk çadırına benzetilen hamam yapısının günümüze ulaşan mimari özelliklerini 18. yüzyıla ait hamam yapılarıyla olan ortak özellikleriyle benzerlikleri nedeniyle bu yüzyılda kazandığı düşünülebilir (Horuloğlu, 1983:117). İlk olarak Trabzon'un fethinin ardından yapılan ve daha sonraki yüzyıllarda da devam ettiği anlaşılan onarımlar nedeniyle Trabzon'daki hamamlardan çok farklı olan bu hamam yapısı şehrin kadim yapılarından biri olarak günümüze ulaşmıştır.

Yapı malzemesi olarak moloz taş, kesme taş ve iç mekânda beyaz mermer kullanılmıştır. Hamam düz bir arazi üzerinde kuzey-güney yönünde yapılmıştır. Tek fonksiyonlu bir yapıdır. Soyunmalık, soğukluk ve sicaklık bölümlerinden oluşur. Günümüze gelene kadar birçok onarımdan geçmiştir. Sekiz sütun üzerine oturtulan büyük kubbesiyle dikkati çeken hamamın yanlarında girişte beşik tonozlu bir mekânı vardır. Kare şeklinde olan sıcaklığın köşelerinde dört küçük halvet yer almaktadır. Soyunma yeri ahşap olduğundan sonradan yıkılmıştır. Hamamın girişi kuzey cephesindedir. Trabzon'daki en eski Türk Hamamı olan eser ayrı bir özellik taşımaktadır (Yüksel, 2000:227). Soyunmalığı Trabzon Belediyesice onarılmıştır. Bugün halen işler durumdadır.

\section{Fatih Hamamı (Hacı Kasım)}

Yapı Cumhuriyet mahallesinde, Paşa hamam sokaktadır. Hacı Kasım camisinin batısında yer alır. Fatih camisinin kitabesi olmadığından kesin yapılış tarihi belli olmamakla birlikte Trabzon'un fethinden sonra yapıldığı anlaşılmaktadır (Yüksel, 2000:228). Bundan dolayı hamamın yapım tarihi de aynı zamana işaret etmektedir.

Bugün büyük bir bölümü yıkılmış durumda olan yapının doğu bölümündeki sıcaklık kısmı ayakta kalmıştır. Batı taraftaki soyunma-soğukluk bölümü tamamen yıkılmıştır. Hamamın sıcaklık bölümüne biri batı cephesinden diğeri soyunma-soğukluk bölümünden olmak üzere iki kapıdan girilir. Sıcaklık, yan yana iki kubbe ile örtülü iki hücreden ve bunlara bağlı iki dikdörtgen odadan oluşmaktadır. Güney kesimindeki hücre ile oda birleştirilerek ortaya göbek taşı konulmuştur. Moloz taşlarla duvarları örülen hamamın tonoz ve kubbeleri tuğladan yapılmıştır.

Günümüze kadar birçok değişiklik ve onarımdan geçmiş olan bu hamam 2008'de geçirdiği kapsamlı restorasyonla (Yüksel, 2000:228) bugün işlevini sürdürmektedir. Vakıflar Genel Müdürlüğü mülkiyetinde olan yapı, erkekler hamamı olarak hizmet vermekte olup, haftanın bir günü kadınlara tahsis edilmiştir. 


\section{İskender Paşa Hamamı}

Çarşı mahallesinde, Taş Han'ın batısında, Çarşı camisinin güneybatısında yer alır. Kaynaklarda Paşa Hamamı olarak da geçen yapı, Trabzon Valisi İskender Paşa'nın 1521-1531 tarihlerindeki Trabzon Valiliği döneminde 1531 yılında yaptırılmıştır (Karpuz, 1990:63 ve Horuloğlu, 1983:119 ve Yüksel, 2000:229). Hamamdan İskender Paşa'nın H.937/M.1531 tarihli vakfiyesinde söz edilmektedir. Çifte hamam olarak doğu-batı yönünde inşa edilmiş olan yapı dikdörtgen bir plana sahiptir. Batısında erkekler hamamı, doğusunda kadınlar hamamı bulunmaktadır. Erkekler bölümüne kuzey cephesindeki Paşa hamam sokağından, Kadınlar bölümüne ise arka taraftan güney cephesinden girilmektedir. Erkekler bölümü, kare bir soyunmalık, küçük bir ılıklık bölümü ve iki küçük ışık kubbesiyle aydınlanan dikdörtgen bir sıcaklık bölümünden oluşur. Kadınlar bölümünün soyunmalık mekânının üzeri fenerle örtülüdür (Özen vd., 2010:129). Yap1 1889, 1938, 1981 yıllarında onarımdan geçirilmiştir (Albayrak, 1999:233). Horuloğlu ve Karpuz'da bu onarımlardan bahsetmektedir. En son 2008 yılında esaslı bir onarım yapılmıştır (V.G.M. Arşivi). Vakıflar Genel Müdürlüğü mülkiyetinde olan yapının halen erkekler ve kadınlar kısmı faaliyet göstermektedir.

\section{Meydan Hamamı}

Kemerkaya mahallesi, Meydan hamamı sokaktadır. Sulu Han'ın güneyinde yer alır. Yapı Kazazzade sülalesinden Hacı İbrahim tarafından yaptırılmaya başlanmış, zamanın Belediye Başkanı Hüseyin Kazazoğlu tarafından 19. yüzyılda tamamlanmıştır (Horuloğlu, 1983:123 ve Karpuz, 1989:128-129). Çifte fonksiyonlu olup bugün faal durumdadır.

Çok fonksiyonlu bir hamamdır. Soyunmalık, llıklık ve sıcaklık bölümlerinden oluşur. Sıcaklık bölümünde dört eyvanlı köşe hücreli plan uygulanmıştır. Kadınlar bölümü kuzey-güney doğrultusunda düzenlenmiştir. Erkekler kısmı doğuda ve iki katlı olarak düzenlenmiştir. Kesme taş malzeme ile yapılmıştır.

Erkekler kısmına kuzey yönden ahşap bir kapı ile girilmektedir. Girişte İki katlı ahşap soyunma yeri vardır. İkinci kata sağlı-sollu merdivenle çıkılmaktadır. Buranın üzeri sekiz ahşap direğin taşıdığı sekizgen çatı ile örtülüdür. Kasnakta yer alan çok sayıda pencere ile soyunmalık aydınlatılmıştır. Dıştan kırma çatılıdır. İçeride soyunma hücreleri mevcuttur.

Ilıklığa batıdan açılan kapı ile girilmektedir. Bu kısımda tuvalet ve temizlik hücreleri bulunmaktadır. Sıcaklık kısmına kemerli bir kapı ile geçilir. Sıcaklığın üzeri kubbe ile örtülmüştür. Yan bölümler sekiz adet küçük kubbe ile kapatılmıştır. Kubbeler iki ayakla desteklenmiştir. Bu kısmın doğu tarafında iki yıkanma hücresine yer verilmiştir. Ortada sekizgen göbek taşı bulunur. Zemin ve yan kısımlar mermer döşelidir. Aydınlatma kubbelerden camlı 1şıklarla sağlanmıştır.

Kadınlar kısmı kuzey-güney doğrultusunda uzanmıştır. Giriş batı taraftadır. Soyunmalığa buradan girilir. Erkekler kısmı gibi düzenlenmiştir. Soğukluk doğu batı yönlü olup, dikdörtgen şeklindedir. İki kubbe ile örtülmüştür.

Sıcaklığa güneyden bir kapı ile geçilmektedir. Bu bölümün üzeri kemerlerin koruduğu büyük bir kubbe ile örtülmüştür. Külhan ve Su deposu hamamın batısında olup, dikdörtgen şeklindedir. Çevresindeki dükkânlar sebebiyle dışarıdan algılanamamaktadır. Vakıflar Genel Müdürlüğü mülkiyetinde olan yapının halen erkekler ve kadınlar kısmı faaliyet göstermektedir. 


\section{DEĞERLENDİRME}

Trabzon Hamamları plan bakımından haçvari dört eyvanlı köşe hücreli gruba girerler. Sadece Sekiz direkli hamam sıcaklık bölümünü taşıyan sekiz sütunla değişik bir düzenlemeye sahiptir. Bu düzenleme Önge'nin XV. yüzyıldan itibaren, soyunma mahallerini örten kubbelerin kasnaklar üzerinde yükseltildiği ve bu kasnaklara da pencereler açıldığı görüşüne bağlanabilir (Önge, 1978:121).

Hamamların soyunmalık bölümleri genelde kare planlı kubbeli veya ahşap örtülü düzenleri ile değişiklikler arz etmektedir. Bunlardan Meydan ve İskender Paşa Hamamları, soyunmalık bölümleri ahşap örtülü ve kare planlıdır. Sıcaklık bölümleri hamamlarda yerleşmiş plan şemasının izlendiği en önemli bölümler olarak görülmektedir. Sıcaklık bölümleri de kubbe ile örtülmüştür. Bu düzenlemeleri ile XVIII. yüzyıl Anadolu hamamları ile benzeşmektedir (Kahrıman, 2003:256).

Trabzon Hamamlarında hamamların soyunmalık kısımlarında ahşap direkler destek unsuru olarak kullanılmıştır (Kahrıman, 2003:269). Kubbeye geçiş elemanı olarak Fatih, Meydan, İskender Paşa' da pandantif kullanılmıştır. Sadece Sekiz Direkli hamamda köşelerde tromplara yer verilmiş olup dışarıya vurgulanmıştır.

Örtü Sistemlerinde ise genellikle kubbe ağırlıklıdır. İçeriden ahşap çatı uygulaması görülür. Tonoz örtüye en çok hamamlarda rastlanır. Beşik ve Aynalı Tonoz en çok kullanılan biçimlerdir. Beşik ve Aynalı tonoz daha çok sıcaklık eyvanları, tuvalet ve temizlik hücreleri gibi ortak kullanıma açık bölümlerde kullanılmıştır. Külhan ve Su depoları da genelde benzer şekilde bir tonozla örtülüdür. Yapıların aydınlatma şekli daha çok tepeden sağlanmaktadır. Kubbe geçişleri kolay algılanır. Hamamların cephe aydınlatılmalarında dikdörtgen formlu pencereler kullanılmıştır. Bu özellik İskender Paşa Hamamında uygulanmıştır.

Tüm yapılarda yapı malzemesi ağırlıklı olarak kesme taş, moloz taş, mermer ve tuğladır. Trabzon Hamamlarında süsleme unsuruna pek fazla rastlanmamaktadır. Süsleme sadece sıcaklık bölümlerinde bulunan göbek taşı, kurnalar ve kurna ayaklarında mermer işlemeli olarak yapılmıştır. Ayrıca hamamların eyvan duvarlarında, iç duvarlarında mermer ve taş işlemeli panolar ile nişler bulunmaktadır (Kahrıman, 2003:265). İç mekânda özellikle sıcaklık kısımlarında mermerin yalınlığı ve zarafeti hâkimdir.

Trabzon hamamları dört eyvanlı, köşe hücreli klasik Osmanlı hamamları anlayışının devamı niteliğindedir. Bu özellikleriyle klasik dönem hamamlarıyla benzeşmektedir. Ancak kendine özgü mimari özellikleri de barındırmaktadır. Bu sebeple Türk hamam mimarisinde önemli bir yere sahiptir. Ayrıca bulunduğu bölgenin yapı karakteriyle aynı eksende bir gelişme göstermiştir. Bu açıdan bakıldığında Karadeniz bölgesinde değerlendirdiğimiz hamamlar plan ve malzeme teknik açısından benzer özellikleri göstermeleriyle de dikkate değerdir.

Trabzon hamam yapılarını Karadeniz bölgesinde yer alan kentlerden Artvin, Giresun ve Gümüşhane'deki hamam örnekleriyle karşılaştırabiliriz. Artvin Kent Hamamı (XVIII. yy.), (Aytekin, 1999:327) Şebinkarahisar'da yer alan Topal Mehmet Paşa (Kurşunlu) Hamamı (1651), (Ayben, 2000:354-355) Gümüşhane Merkez (Eski kent) Kavaklık Hamamı (XVII-XVIII. yy), (Sarıhan, 2004:49) benzer örneklerdir. 
Şekil 1 Artvin Merkez Çarşı Hamamı (XVIII. yy.)

(Çiz: Haşim Karpuz)
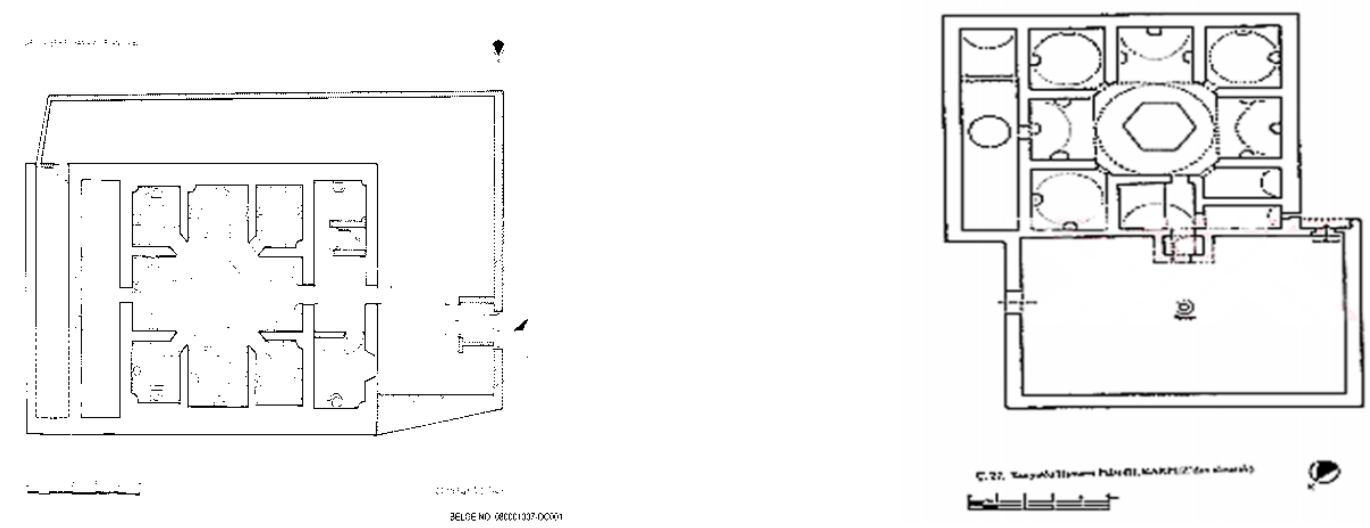

Şekil 2 Giresun Kurşunlu Hamamı (1651)

(Çiz: V.G.M. arşivi)
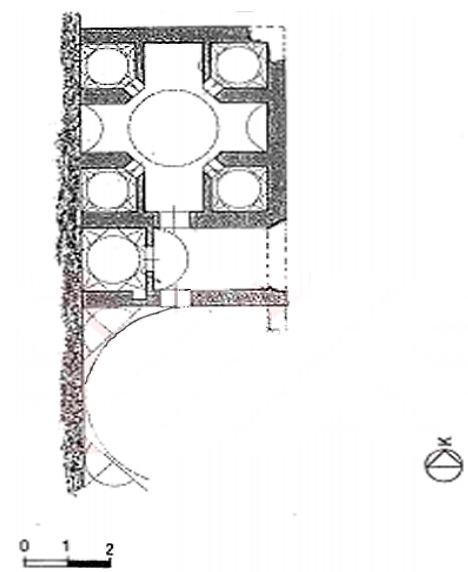

Şekil 3 Gümüşhane Merkez (Eski kent) Kavaklık Hamamı (XVII-XVIII. yy)

(Çiz: G. Akagün)

Her üç yapıda da plan özellikleri Trabzon hamamlarıyla benzerdir. Dört eyvanlı köşe hücreli plan tipinde olup, Klasik Osmanlı özelliği gösterir. Dönem özellikleri itibariyle XVII-XVIII. yüzyıllara tarihlendirilirler. Malzeme açısından da benzerlik göstermektedir Kesme taş, moloz taş kullanılmıştır. Yapılarda tonoz örtü ağırlıktadır. Eyvanlar tonoz halvetler kubbe örülüdür. Yine yüksek 1Sı ve nemden dolayısıyla yapılarda süslemeye fazla yer verilmemiştir.

\section{SONUÇ}

Trabzon İl Merkezinde yer alan hamamlar bugüne kadar tek başına akademik anlamda bir çalışmaya konu olmamıştır. Bu bakımdan bizce büyük öneme sahip olan bu yapıların araştırılıp incelenmesi hayli değerli hale gelmiştir.

Trabzon İl Merkezde bulunan hamam yapıları geneline baktığımızda Klasik Osmanlı dönemi plan tipinin; dört eyvanlı köşe hücreli şemanın çeşitli varyasyonlarının geniş ölçüde uygulandığı görülmektedir. Bölgesel özelliklerde dikkate alındığında doğu Karadeniz çevresinde gerek plan gerekse malzeme teknik özellikleriyle Trabzon hamamları da önemli bir çeşitlilik yaratarak Türk sanatına ciddi bir katkı sağlamıştır. 
Günümüze kadar gelebilen Sekiz Direkli, Fatih, Meydan ve İskender Paşa hamamları her ne kadar yüzyıllar içerisinde çok zarar görmüş olsa da restorasyon çalışmaları sayesinde bugüne ulaşarak özgünlüğünü korumaya devam etmektedir.

\section{KAYNAKÇA}

Akok, M. (1969). Ankara Şehrindeki Roma Hamamı, Türk Arkeoloji Dergisi, (XVII-1), Ankara, Türk Tarih Kurumu Basımevi.

Albayrak H. (1999). Fatihten Kanuniye Trabzon, Trabzon, T.C. Trabzon Valiliği İl Kültür Müdürlügü Yayınları.

Arık R. (2000). Kubadabad Selçuklu Saray ve Çinileri, İstanbul, Türkiye İş Bankası Kültür Yayınları.

Aru K. A. (1949). Türk Hamamları Etüdü, İstanbul, İstanbul Matbaacılık.

Ayben D. (2000). Giresun ve İlçelerindeki Türk Devri Mimari Eserleri, Basılmamış Yüksek Lisans Tezi, Van, Yüzüncü Yıl Üniversitesi.

Aytekin O. (1999). Ortaçağ'dan Osmanlı Dönemi Sonuna Kadar Artvin'deki Mimari Eserler, Ankara, Kültür Bakanlığı Yayınları.

Başkan, S. (1990). Ortaçağ Anadolu'sundaki Türk Sanatının Oluşumu, Türkiyemiz, (62), Ekim, 4247.

Başkan, S. (2012). Semerkant Şah-ı Zinde Yapıları Vakıflar Dergisi, Başbakanlık Vakıflar Genel Müdürlüğü Yayını (37) Haziran, Ankara, 131-166.

Başkan S. (2014). Başlangıcından Cumhuriyet Dönemine Kadar Türklerde Resim, Atatürk Kültür Dil ve Tarih Yüksek Kurumu Başkanlığı, Ankara, Atatürk Kültür Merkezi, 51-52.

Bostan, H. (2002), XV-XVI. Asırlarda Trabzon Sancağında Sosyal ve İktisadî Hayat, Ankara.

Çakmak, C. (2002). Tire Hamamları, Ankara, T.C. Kültür Bakanlığı Yayınları.

Çelebi, E. (1993). Seyahatname (Çev: M. Çevik), 1-2, İstanbul.

Erat, B. (1997). Anadolu'da XIV. Yüzyıl Hamam Mimarisi, Basılmamış Doktora Tezi Ankara, Ankara Üniversitesi.

Erken, S. (1973). Edirne Hamamları, Vakıflar Dergisi, 10, 403-419.

Ebru E. (2003). Salnamelere Göre XIX. Yüzyılın Son Çeyreğinde Trabzon Vilayeti Yakınçağ Tarih Ana Bilim Dalı, Yayınlanmamış Yüksek Lisans Tezi, Ankara, Gazi Üniversitesi.

Eyice, S. (1997). Hamam, Türkiye Diyanet Vakfı İslam Ansiklopedisi, c. 15, Türkiye Diyanet Vakfı İSAM, İstanbul, 402-430.

Eyice, S. (1960). İznik'de Büyük Hamam ve Osmanlı Devri Hamamları Hakkında Bir Deneme, İstanbul Üniversitesi Edebiyat Fakültesi Dergisi, (XI):15, 99-120.

Fatsa, M. (2015). Trabzon Yöresinin İslamlaşma Süreci ve Zaviyeler, Karadeniz İncelemeleri Dergisi, (18): 61-74.

Horuloğlu, Ş. (1983). Trabzon ve Çevresinin Tarihi Eserleri, Trabzon.

İnan K. (1998). Kadı Sicillerine Göre Trabzon Şehrinin Fiziki Yapısı (1643-1656), Osmanlı Araştırmaları, (XVIII), İstanbul, 161-186. 
Kahrıman, Ö. (2003). Trabzon'daki Türk Devri Mimari Eserleri, Basılmamış Yüksek Lisans Tezi, Erzurum, Atatürk Üniversitesi.

Kuban, D. (1977). 100 Soruda Türkiye Sanatı Tarihi, 7. Baskı, İstanbul, Gerçek Yayınevi.

Karpuz, H. (1994). Trabzon'da Yok Olan Bazı Türk Devri Yapıları, Vakıflar Dergisi (XXIII), Ankara, 145-160.

Karpuz, H. (1989). Trabzon'daki Türk Devri Hamamları, 88-89 Trabzon Kültür ve Sanat Yıllığ 1 (2), İstanbul, Trabzonlular Kültür ve Dayanışma Derneği Yayınları, 109-135.

Lowry, H. W. (2005). Trabzon Şehrinin İslamlaşma ve Türkleşmesi, İstanbul, Boğaziçi Üniversitesi Yayınevi.

Sarıhan M. (2004). Gümüşhane'deki Türk Dönemi Mimari Eserleri, Basılmamış Yüksek Lisans Tezi, Van, Yüzüncü Yıl Üniversitesi.

Şapolyo, E. B. (1967). Türk Hamamları, Ön Asya Dergisi, (3):28, 10-11.

Tuluk, İ. ve Düzenli, İ. (2010). Trabzon Kent Mirası (Yer-Yapı-Hafıza), İstanbul, Klasik Yayınları.

Turan, O. (1997). Selçuklu Tarihi ve Türk İslam Medeniyeti, İstanbul, Boğaziçi Yayınları.

Türkmenoğlu, M. A. (2016). XVII. Yüzyıl'ın İkinci Yarısında Trabzon, (Şer'iyye Sicillerine Göre), Basılmamış Doktora Tezi, Konya, Selçuk Üniversitesi.

Usta, S. (2016). Trabzon İmâret-i Hatuniye Vakfı ve Gelirleri (1550-1650), Karadeniz İncelemeleri Dergisi, (21): 225-250.

Usta V. (1999). Anabasis'den Atatürk'e Seyahatnamelerde Trabzon, Trabzon, Serander Yayınları.

Uzun, M. ve Albayrak, N. (1997). Hamam, Türkiye Diyanet Vakfı İslam Ansiklopedisi, İstanbul, Türkiye Diyanet Vakfı İSAM, (15): 430-433.

Melek, Ö. (2005). Kuruluşundan 19. Yüzyıla Kadar Trabzon Tarihine Kısa Bir Bakış, Karadeniz Araştırmaları Balkan, Kafkas, Doğu Avrupa ve Anadolu İncelemeleri Dergisi. Ankara, Karadeniz Araştırmaları Merkezi, (5): 11-25

Önge, Y. (1978). Eski Türk Hamamlarında Aydınlatma, Vakıflar Dergisi (XII), Ankara, 121-136.

Önge, Y. (1995). Anadolu'da XII-XIII. Yüzyıl Türk Hamamları, Ankara, Vakıflar Genel Müdürlüğü Yayınları.

Önge, Y. (1988). Anadolu Türk Hamamları Hakkında Genel Bilgiler ve Mimar Koca Sinan'ın İnşa Ettiği Hamamlar, Mimarbaşı Koca Sinan Yasadığı Çağ ve Eserleri, I, İstanbul, Vakıflar Genel Müdürlüğü Yayınları, Ayrı Basım, 403-428.

Özen, H. (2010). Trabzon Kent İçi Kültür Varlıkları Envanteri, Trabzon, Trabzon Valiliği Yayınları.

Yegül, F. (2009). Anadolu Su Kültürü: Türk Hamamları Yıkanma Geleneğinin Kökleri ve Geleceği, Anatolia, (35): 99-118.

Yüksel M. (2000). Trabzon'da Türk-İslam Eserleri ve Kitabeleri, 5, Trabzon, Trabzon Belediyesi Kültür Yayınları. 


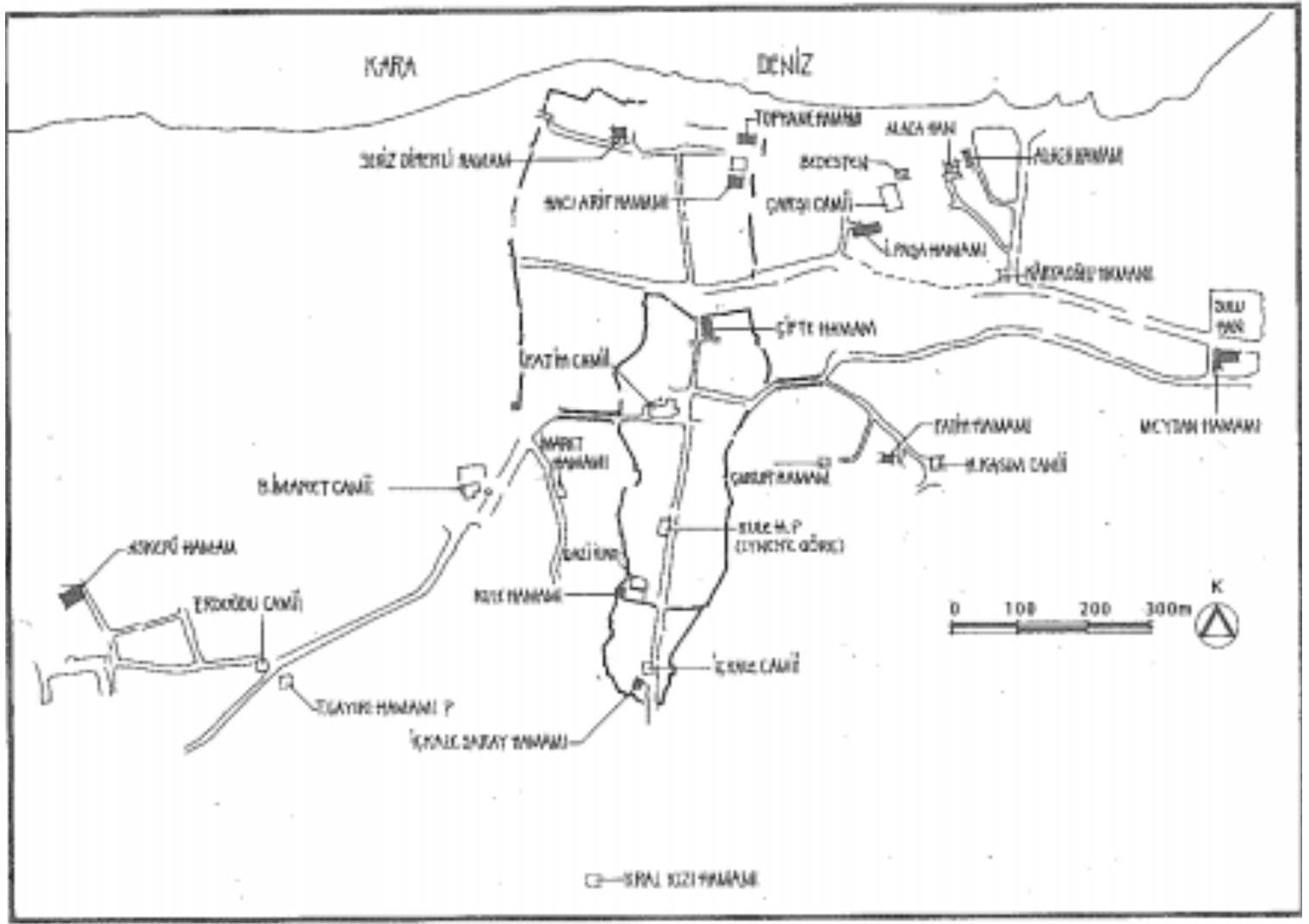

ÇIZIM : 1 TRABZONDAKI TÜRK DEVRI HAMAMLARININ YERLERINI,GŌSTE RIR KROKI

Çiz: Haşim Karpuz'dan (1988)

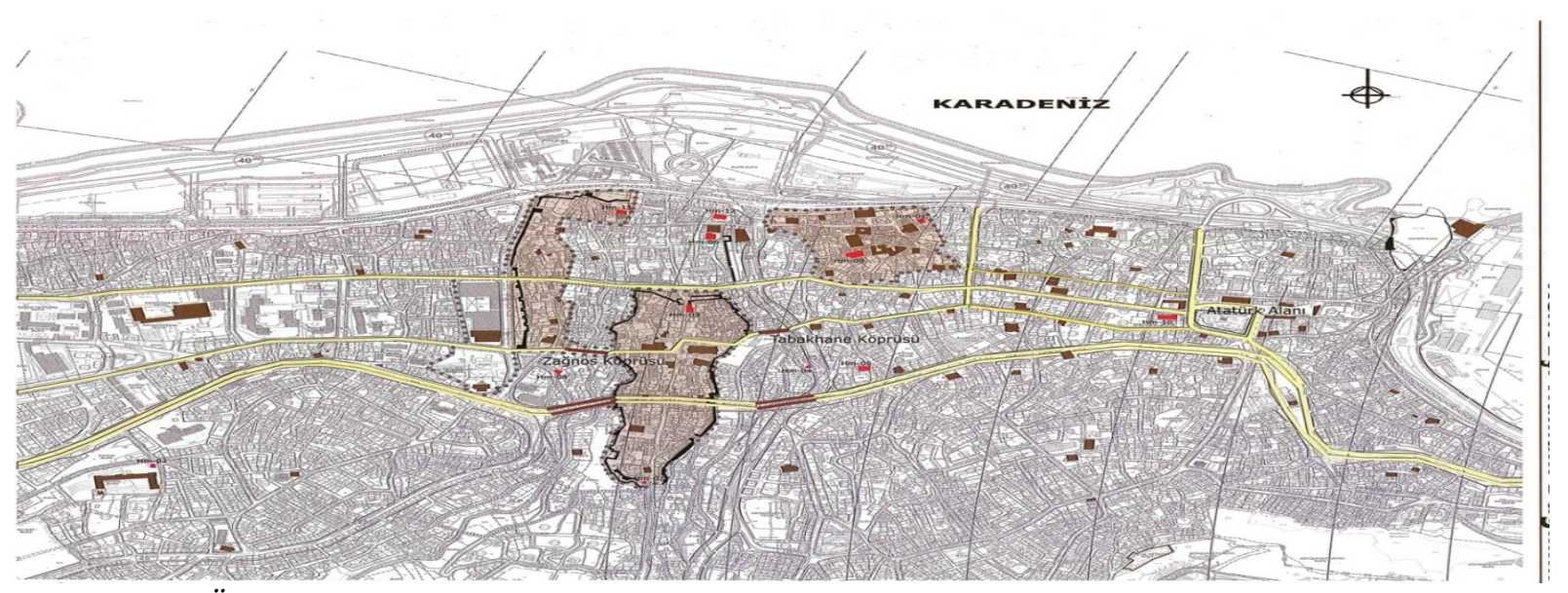

Çiz: Hamiyet Özen'den (2010)

Res.1/1Sekiz Direkli Hamam'ın Günümüzdeki Durumu Çiz.1/1 AYÇA SÜRÜL'den (2003) 


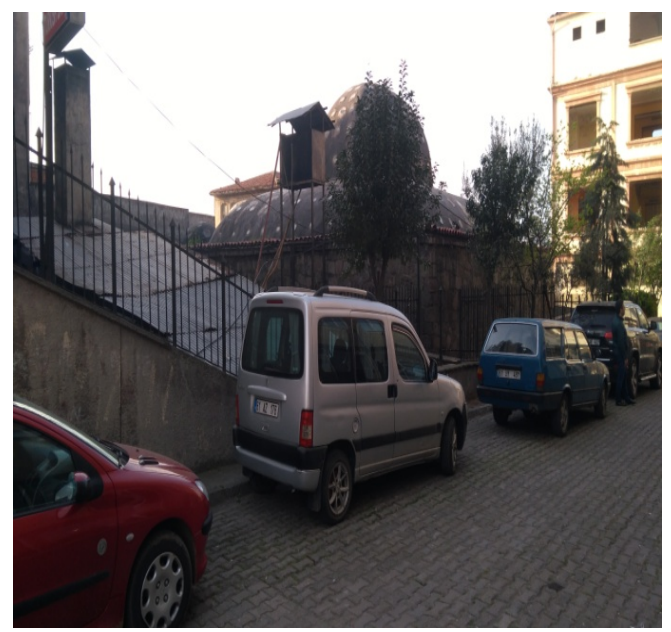

Res:1/2 Hamam Girişinden görünüm

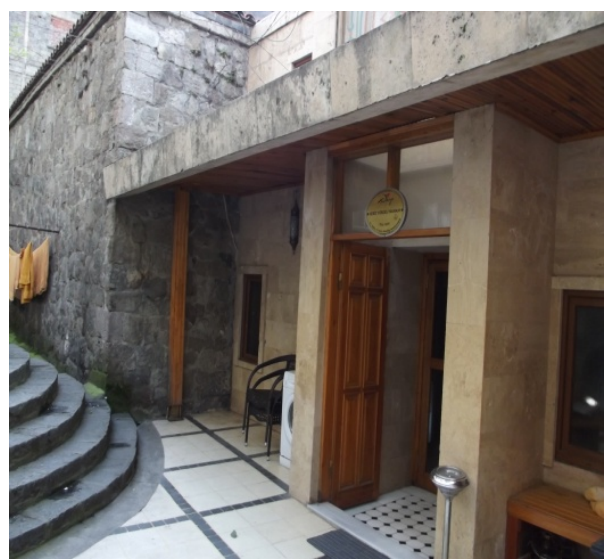

Res:1/4 İç mekândan görünüm

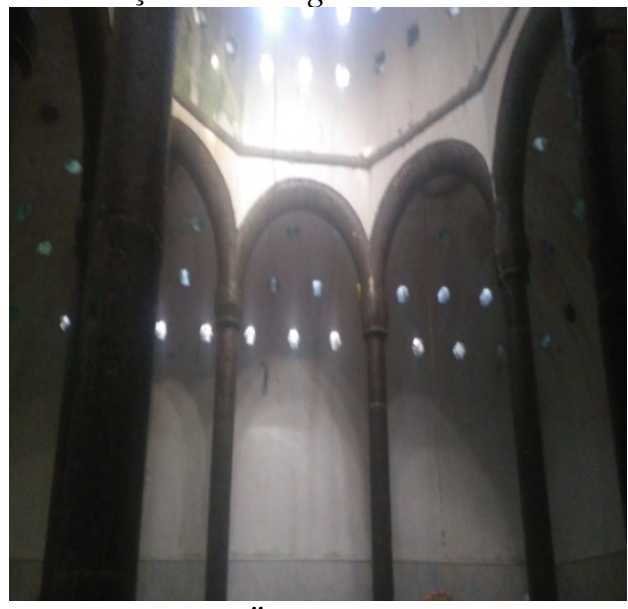

Çiz:2/1Hamiyet Özen (2010)

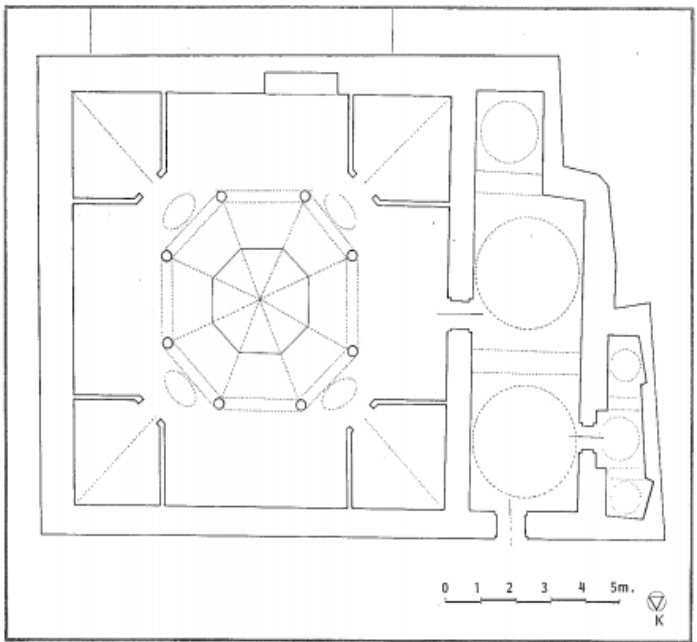

Res:1/3Soyunmalk görünüm

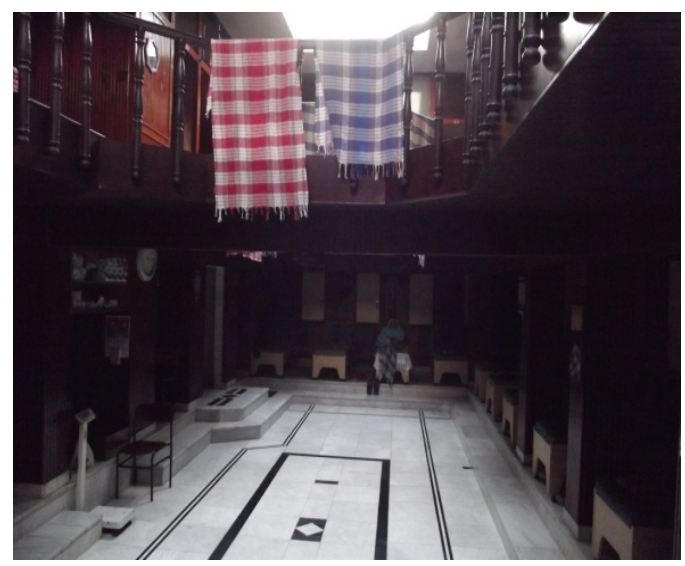

Res:1/5 Kubbeden görünüm

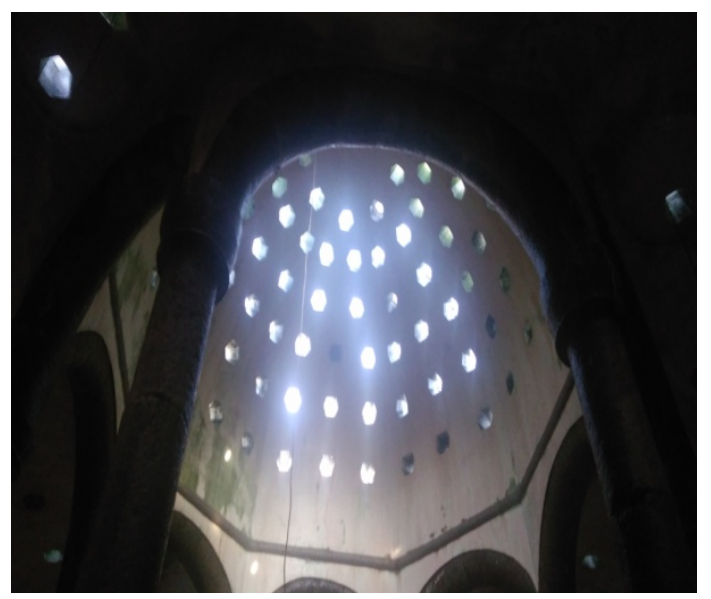

Res:2/1Fatih (Hacı Kasım ) Hamamı 


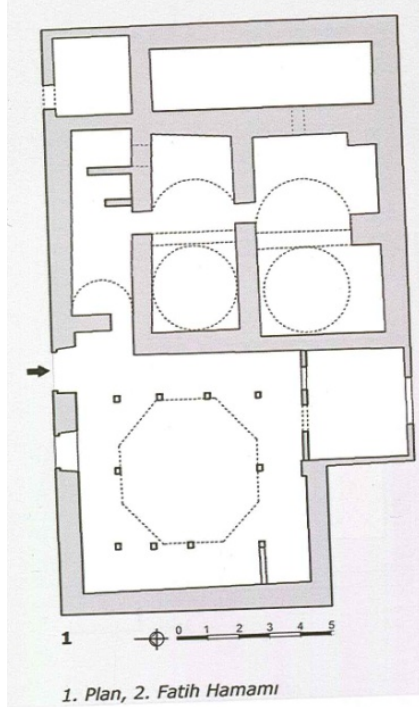

Res:2/2 Hamam Giriş

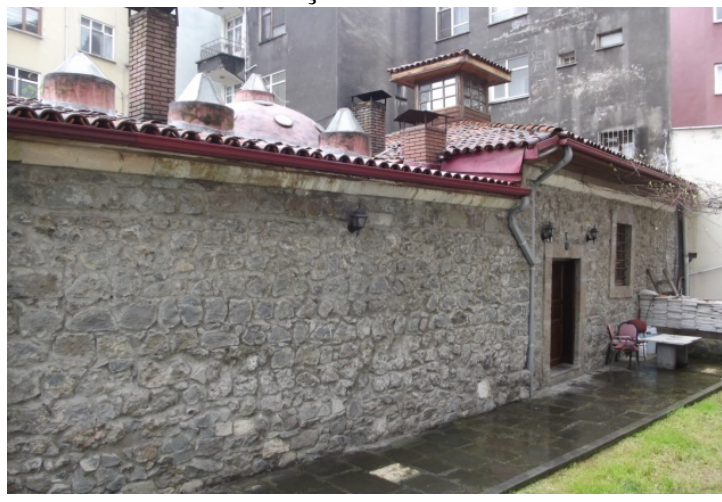

Res:2/4 Hamam örtüsü görünüm

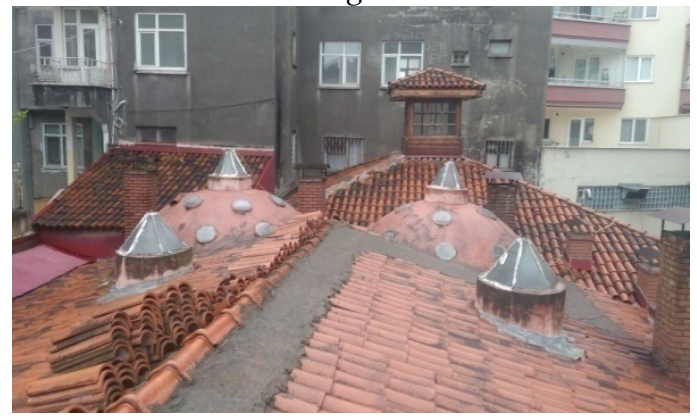

Re:2/6Sıcaklık göbek taşı

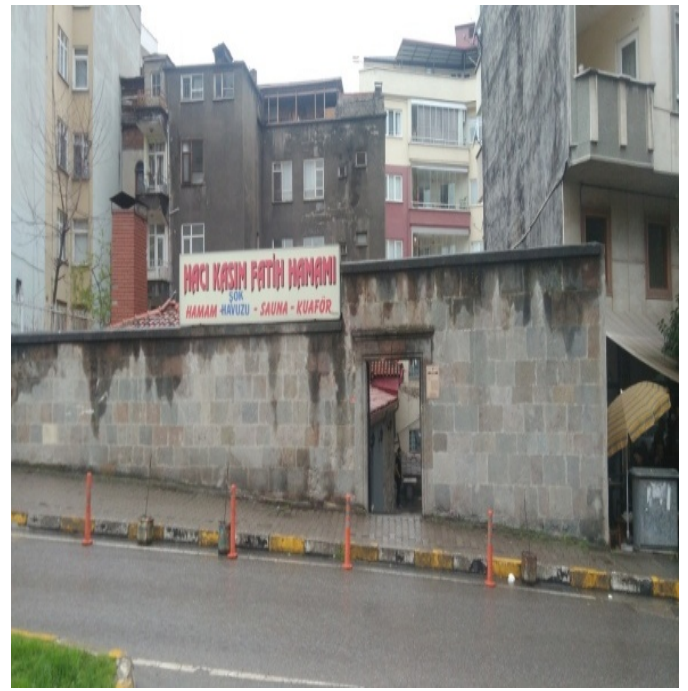

Res:2/3 İç Mekan Örtüsü

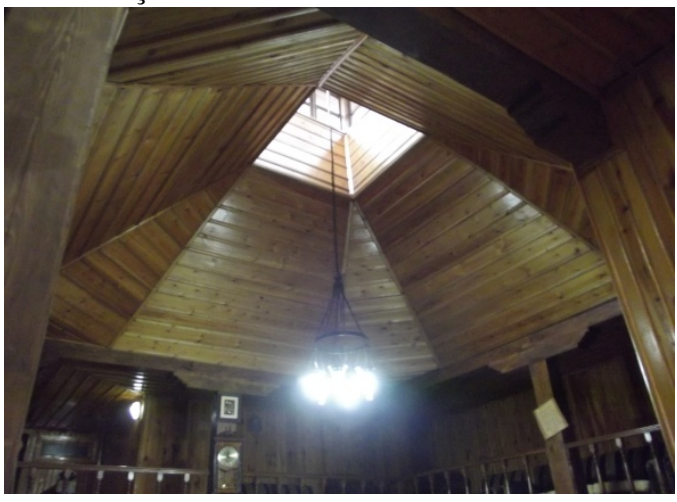

Res:2/5 Soyunmalıktan görünüm

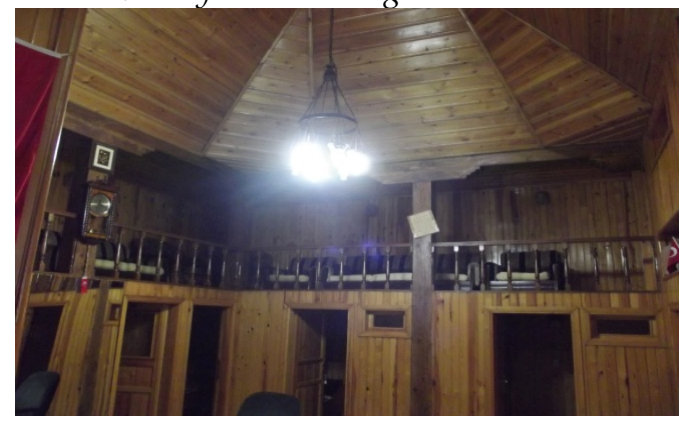

Res:2/7 İç mekân kurnalar 


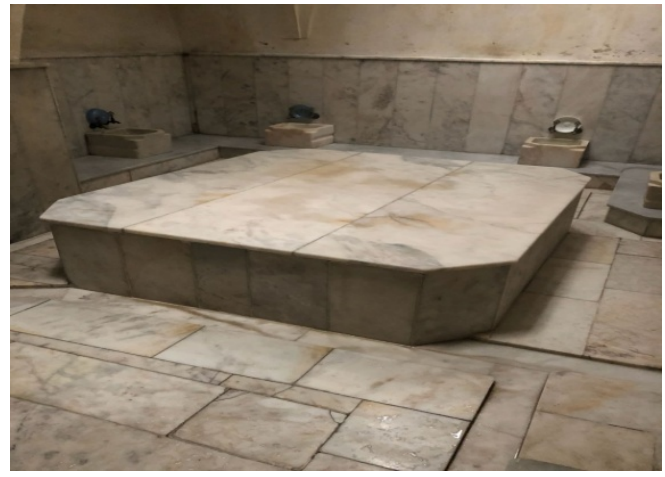

Res:3/1İskender Paşa Hamamı Giriş̧i

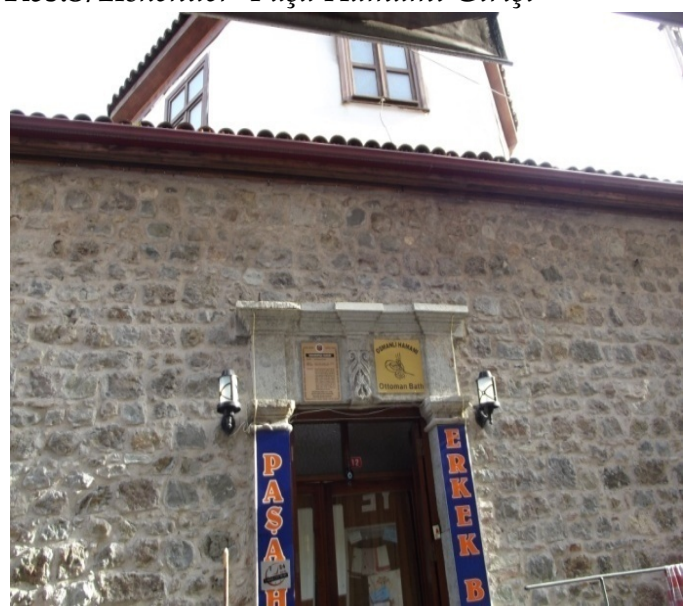

Res:3/2 Kubbeden Görünüm

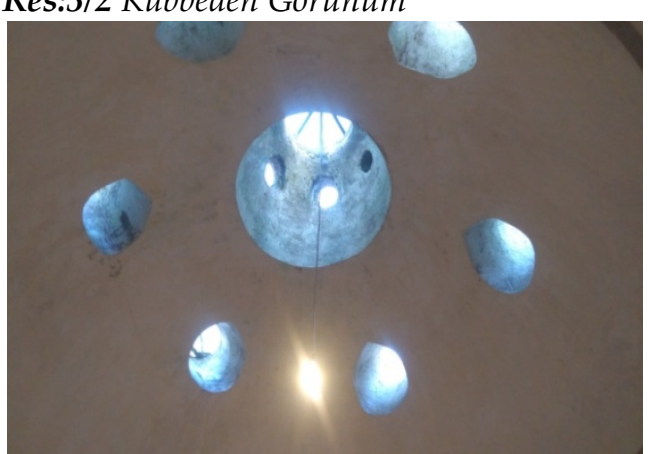

Res:3/4Soyunmalık görünüm

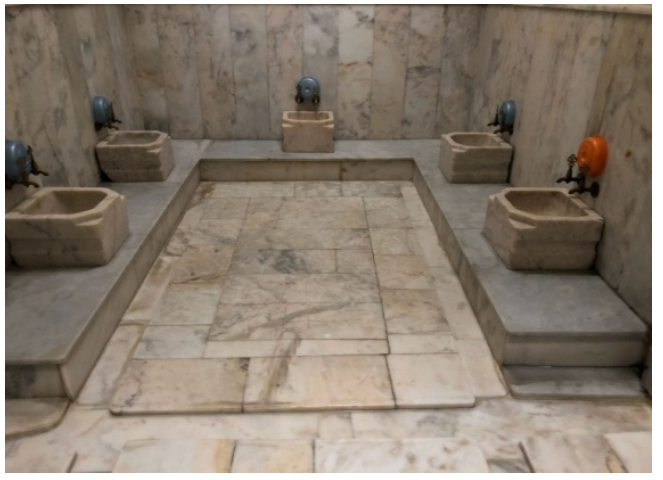

Çiz.3/1 (T.K.T.V.K.K. Arşivi)

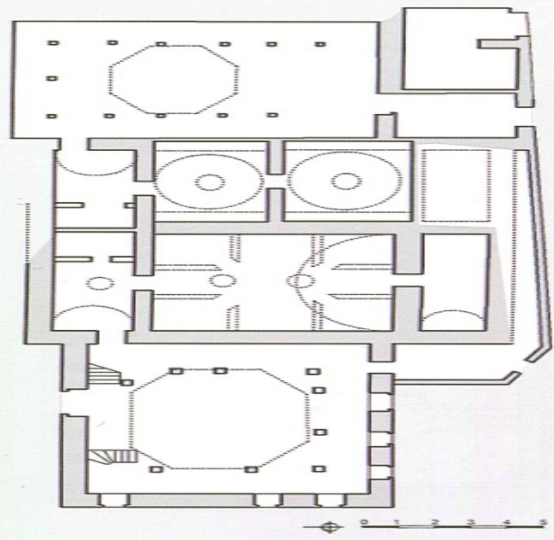

Res.3/3 Çatı Örtüsünden Görünüm

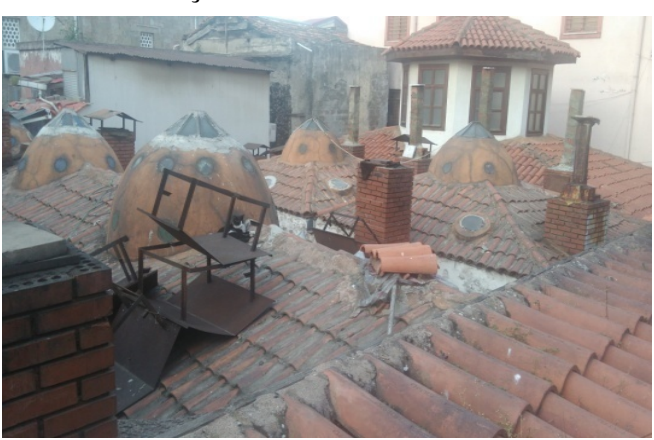

Res:3/5 İç mekân sıcaklık 


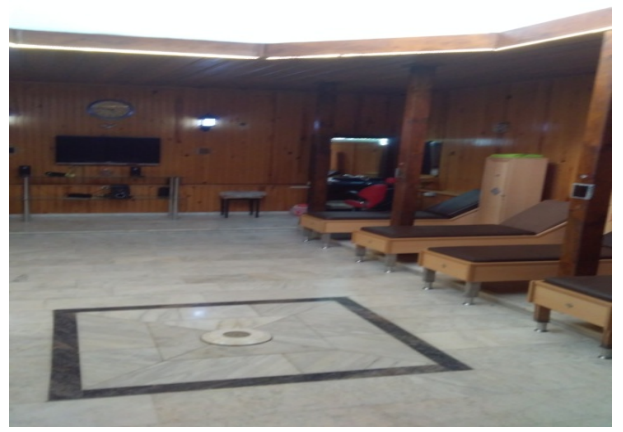

Res:3/6Sıcaklık kısmından görünüm

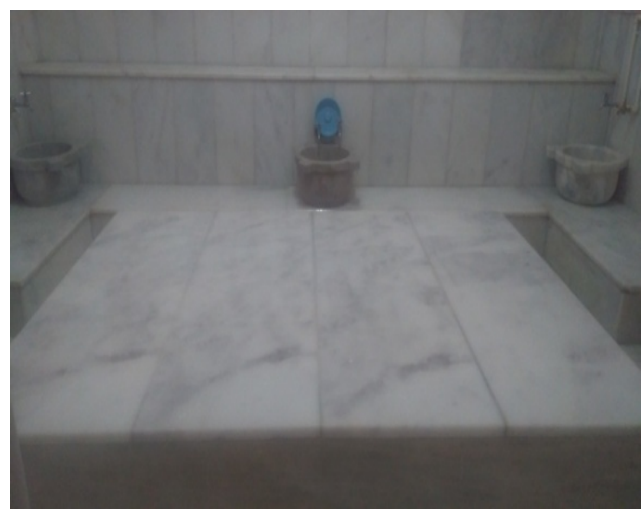

Res:4/1 Meydan Hamamı

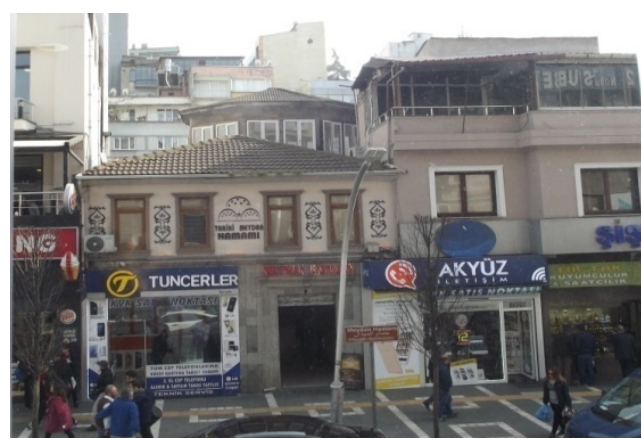

Res:4/2Erkekler bölümü sıcaklı̆̆ı göbek taşı

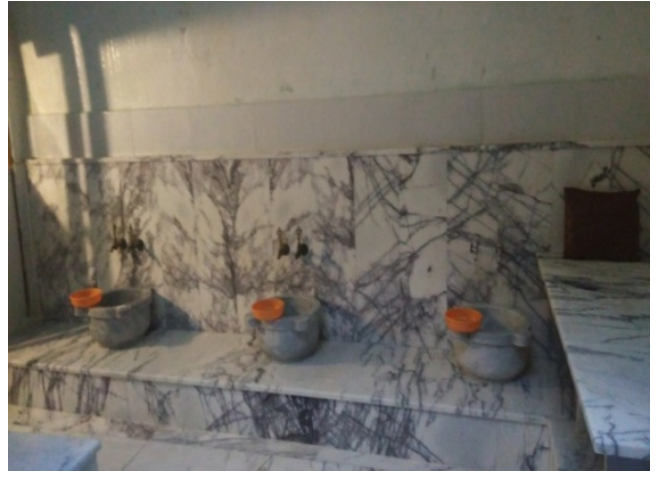

Res:3/7 Sıcaklık kısmından görünüm

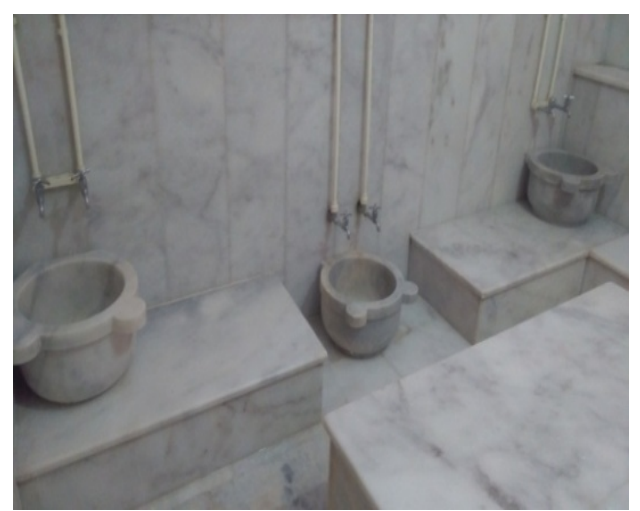

Çiz.4/1 (T.K.T.V.K.K. Arşivi)

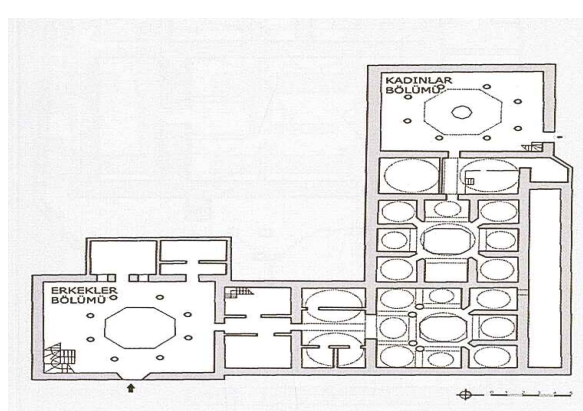

Res:4/3 Erkekler bölümü sıcakllğg kurnalar 


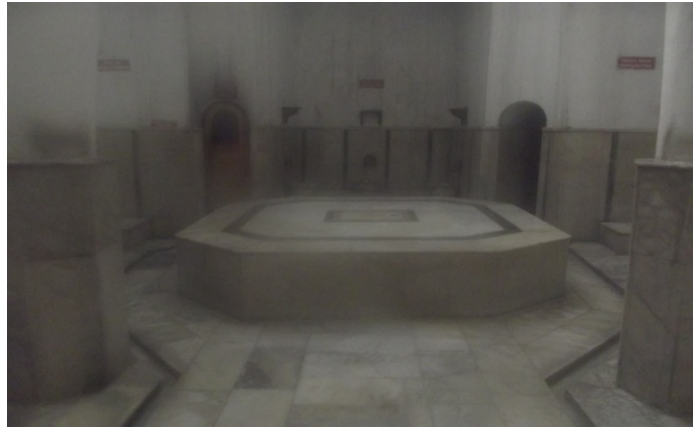

Res4/4Bayanlar Kısmı Girişi

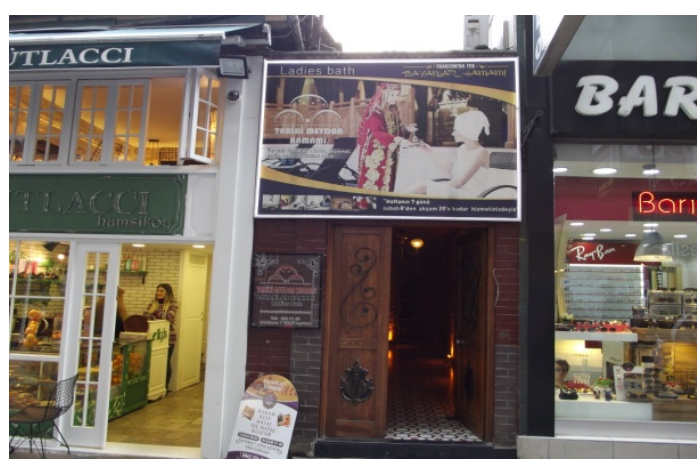

Res4/6 BayanlarKısmı göbektaşı

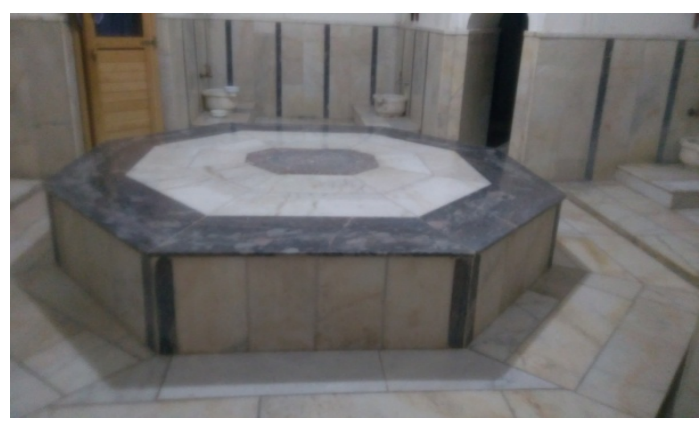

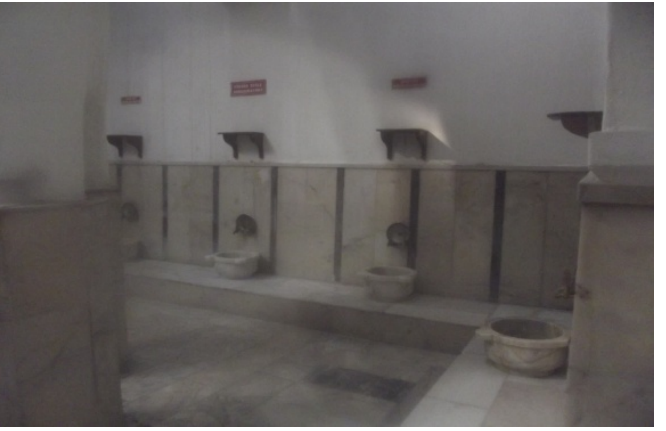

Res:4/5 Sıcaklık kubbesinden görünüm

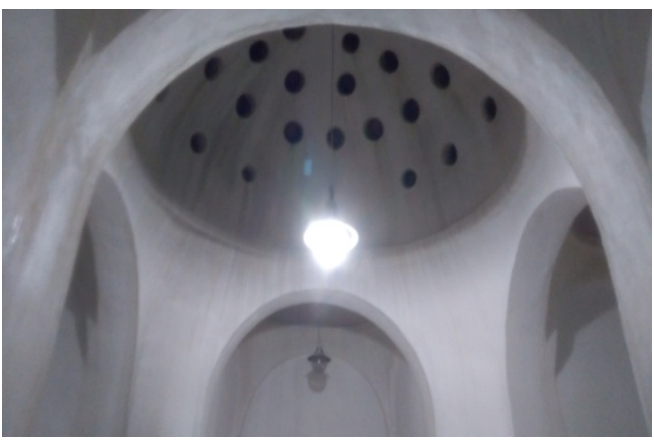

Res4/7Bayanlar Kısmı sıcaklık kurnalar

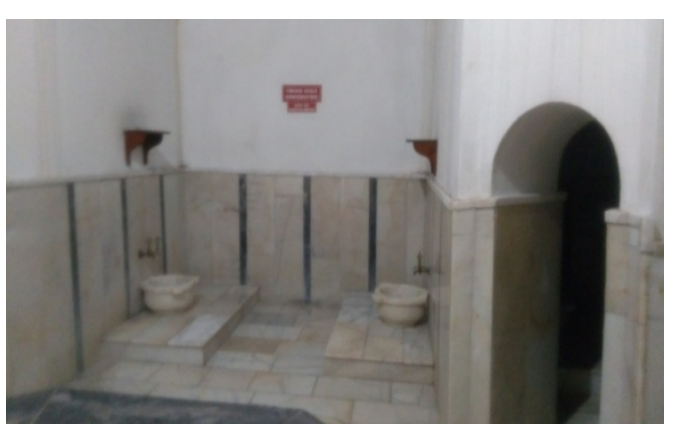

